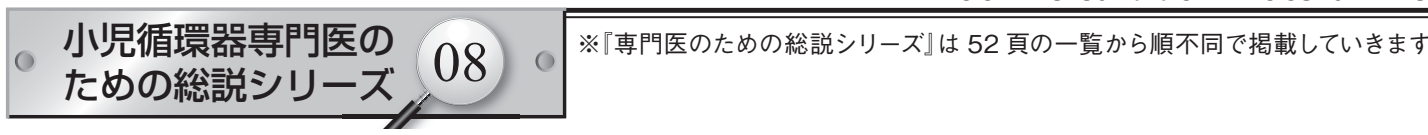

\title{
超音波検查の原理から応用
}

富松 宏文
東京女子医科大学循環器小癿科

\section{Principles and Applications of Echocardiography}

Hirofumi Tomimatsu

Department of Pediatric Cardiology, Tokyo Women's Medical University, Tokyo, Japan

Echocardiographic imaging and Doppler systems generate ultrasound signals that follow the laws of physics. Appropriate utilization of these instruments and interpretation of the data generated require an understanding of the fundamental principles of ultrasound physics and how they relate to the images produced and the spectral and color Doppler information. This understanding is considered an important requirement for clinical competence in all modalities of echocardiography.

An essential component of the diagnostic accuracy of echocardiography is the skill and experience of the individual responsible for image and data acquisition.

Technical skills includes appropriate knowledge of ultrasound instrument settings such as transducer frequency, use of depth, gain, time-gain-compensation, dynamic range, filtering, velocity scale manipulations, and display of received signals.

Echocardiography is a powerful diagnostic tool that provides immediate access for the evaluation of cardiac and vascular structures and assessment of heart function. Intrinsic to a competent echocardiographic examination is a thorough understanding of the anatomy and physiology of the heart and great vessels. Two-dimensional imaging can accurately quantify cardiac chamber sizes, wall thickness, ventricular function, valvular anatomy, and great vessel size. Pulsed, continuous-wave, and colorflow Doppler echocardiography, especially when combined with two-dimensional imaging, can be used to quantify blood flow velocities and calculate blood flow; assess intracardiac pressures and hemodynamics; and detect and quantify stenosis, regurgitation, and other abnormal flow states.

A segmental approach is the important and useful way to diagnose congenital heart disease.

I will describe the fundamental knowledge of ultrasound, basic views, and segmental approach for congenital heart disease in this paper.

要旨

小児循環器診療の場における心エコー検査の重要性は言うまでもなく, 聴診器とほぼ同様に装置があれば誰にでも 安全に検査することができる。しかし，誰にでも検査することはできるが，誰でも正しい診断ができるとは限らない．

先天性心疾患における心エコー検査はこれまで形態診断が主なものであったが, 最近では機能解析の方法が種々 開発され，先天性心疾患にも応用されつつある.

心エコーを用いて正しい診断をし, 診療に役立てるためには, (1) 超音波の特性やアーチファクトなどの知識, (2) 正常心と先天性心疾患の形態的特徵についての知識, (3) 血行動態についての知識が必要である.

本稿では超音波の基礎と基本的断面および区分診断法の手順につき概説する。

\section{はじめに}

心エコー検査は侵襲がなく, 装置があれば誰にでも 行うことのできる検査である。また，その場で多くの
情報をもたらしてくれるため, 診療の場では必須の検 査となっている。しかし，その検査所見を正しく判断 し診療に役立てるためには超音波の基礎と心疾患の形 態や血行動態についての知識が必須である。これらを 
理解していなければ診療に役立たないばかりか，工 コー検査があるがために誤診をする“エコー病”を作 ることにもなりかねない．

\section{1. 超音波の基礎と超音波診断装置}

超音波の基礎についてはどの超音波医学関係の教科 書にも最初の項に記載されているにもかかわらず，読 まれることは少ない。ここでは, 実際に臨床の場で知っ ておくべき必要最小限の知識について述べる. 物理学 的な詳しいことは成書で勉強していただきたい1,2).

\section{1. 超音波とは}

超音波とは, “人の耳に聞こえない程度の高い周波数 の音波”と定義されることが多く, 一般には $20 \mathrm{kHz}$ 以 上の高い周波数の音波である. 通常の超音波診断にお いて用いられるのは, $2 \mathrm{MHz}$ から $30 \mathrm{MHz}$ 程度である。

\section{2. 超音波の性質}

\section{1) 周波数}

周波数が高いと直進性が高く，指向性が高くなる. しかし, 逆に減衰が大きくなり到達距離は短くなる。 また, 周波数が高いほど得られる画像の解像度は高く なる，通常の胸壁エコーでは新生児でも $12 \mathrm{MHz}$ 程度 までの周波数が用いられる. それ以上の周波数のもの は血管内エコーとして冠動脈内の様子を観察するのに 用いられる。

\section{2) 反射, 屈折}

超音波は反射をする。探触子から送信した超音波が 生体内を伝播し臟器などで反射し, 反射した超音波が 探触子に帰ってきて初めて画像がつくられる。この反 射がなければ情報は全く得られないことになる，反射 は音響インピーダンスの異なる二つの組織の境界面で 生じる。

音響インピーダンス $=($ 組織の密度 $) \times($ 組織内の音速 $)$ により規定される。通常生体内の軟部組織の中の音速 はほぼ一定であり，JIS 規格により $1,530 \mathrm{~m} / \mathrm{sec}$ と仮定さ れている(Table 1) $)^{3,4)}$.

超音波も光と同様に境界面に対してある角度で入射 すると屈折を来す。これは入射角度に規定され (Snell の法則)，エコー像にひずみが生じる原因となる。

\section{3)減衰}

超音波が伝播しながらその強度が減少することを減 衰という。そその原因には，吸収，拡散，散乱などがある。 生体内では吸収が主な原因となり，

減衰 $=$ 減衰係数 $\times$ 通過距離 $\times$ 周波数

であらわされる。したがって，周波数が高いほど吸収 されやすく遠くまで届きにくいことがわかる.

\section{4) 回折, 干渉}

超音波が遮断されて届かない場所にも音波が回り込 んで到達することを回折といい, 複数の波が存在する ときそれらの波の位相の差により打ち消しあった増幅 することをいう．

\section{5)ドプラ効果, ドプラ法}

音源が動いているときには, その音源の速度と方向 に応じて到達する超音波の周波数が音源の出す周波数 から偏位する現象をいう。赤血球は超音波を反射させ ながら動いているため, 音源が動いていることになる. したがって, 赤血球で反射した超音波が探触子に到達 するときには探触子が送信した周波数と異なって いる.

パルスドプラ法では任意のポイントに打ける血流情 報が得られるが，計測できる最大流速には限界がある． 限界を超えた流速の場合には反対向きの血流として表 示される, 折り返し現象が生じる。連続波ドプラ法で は, サンプルポイントの特定はできず観測線上の最大 流速を測定することになるが，測定できる流速に制限 はない.カカラードプラ法は基本的にはパルスドプラ法 と同じである. 画面上に設定したピクセルの中の平均 流速と方向を求めカラー表示させて B モード画像と重 ね合わせて表示する。

\section{3. 超音波診断装置}

超音波診断装置は, 1) 超音波を発生させ送受信する 探触子, 2) 受診した超音波を電気信号に変換させ画像 を作るための信号処理回路, 3) 作られた画像を表示す るディスプレイなどにより構成される.

心臓では狭い胁間から広い範囲を見るためにセク夕 スキャンが主に用いられる，以前は探触子ごとに送信 する周波数が固定であったが, 最近は広带域の探触子 が用いられる。しかし, 体格に応じて中心周波数の異 なる探触子を用いたほうがより良い画像が得られるこ とが多い

装置本体には, (1)超音波出力, (2)コントラスト(ダイ 
Table 1 生体内の音速と音響インピーダンス

\begin{tabular}{c|c|c}
\hline 組織 $($ ヒト $)$ & 音速 $(\mathrm{m} / \mathrm{sec}) \times 10^{3}$ & 音響インピーダンス $\left(\mathrm{kg} / \mathrm{m}^{2} \cdot \mathrm{sec}\right) \times 10^{6}$ \\
\hline 水晶体 & 1.641 & 1.64 \\
肝臓 & 1.549 & 1.65 \\
脾臓 & 1.566 & 1.64 \\
腎臓 & 1.561 & 1.62 \\
笳肉 & 1.585 & 1.7 \\
脂肪 & 1.45 & 1.38 \\
骨 & 3.38 & 6.08 \\
血液 & 1.57 & 1.61 \\
水 & 1.497 & 1.49 \\
\hline \multicolumn{2}{|c}{}
\end{tabular}

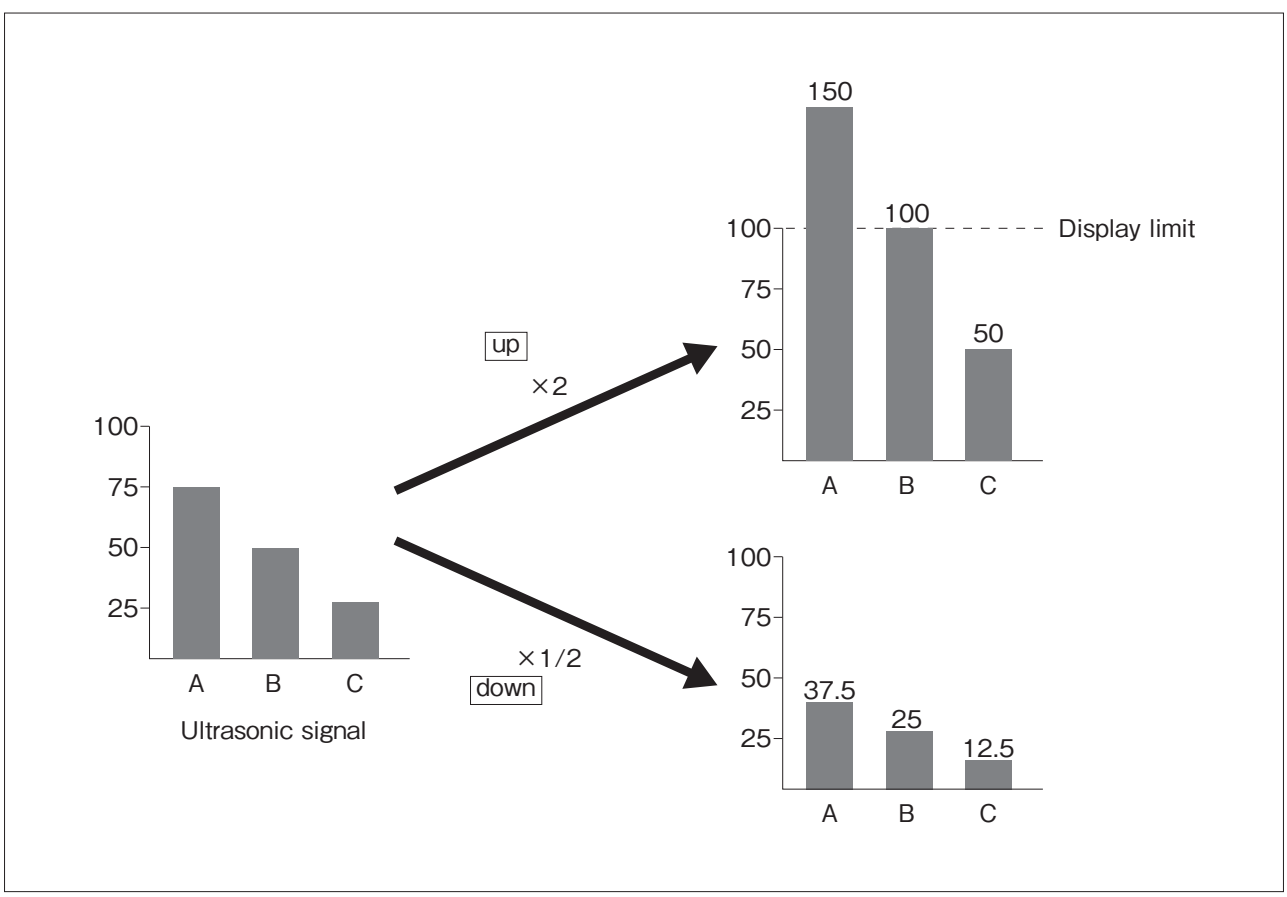

Fig. 1 Contrast

ナミックレンジ), (3)ゲイン, (4) STC (sensitivity time control)あるいは TGC(time gain compensation), (5)周波 数，(6)フレームレート，(7)流速レンジ，などのつまみが あり, これらを調整し見やすい(診断しやすい)良好な 画像を作る。

1) 超音波出力

探触子から送信する超音波の強さを調節する。通常 はその装置の最大值にしておく。まれに，人工物など 反射の強い構造物を見るときには, 出力を落とすと画 像が見やすくなることがある.

\section{2) コントラスト(ダイナミックレンジ)}

画像の白黒の差を調整するもので，コントラストを 強めると白黒の差ははっきりし硬い画像になる。一方 コントラストを下げると白黒の差が小さくなりやわら
かい画像になる。すなわち，元の信号に掛け算をした り, 割り算をしたりして画質を変えていることになる (Fig. 1).

\section{3) ゲイン}

画像全体の信号の強さを上げたり，下げたりするも のであり，ゲインを上げると画像全体が白くなるが， 白黒の差が大きくなるわけではない。すなわち元の信 号に足し算をしたり，引き算をしたりして画質を変え ることになる (Fig. 2).

4) sensitivity time control (STC)もしくは time gain compensation (TGC)

超音波は深い位置に行くほど減衰し, 超音波は弱く なり得られる信号も弱くなる. STC は深さごとにゲイ 


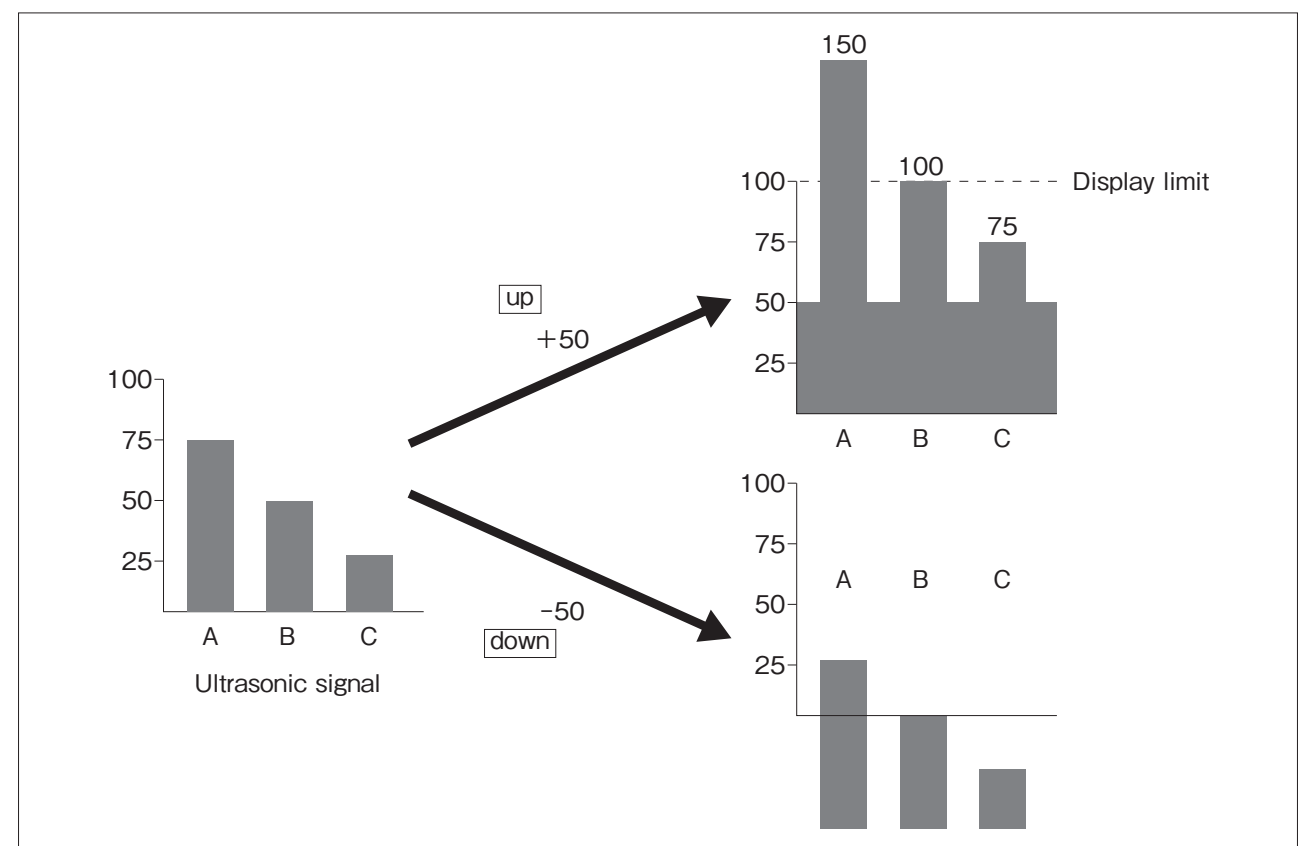

Fig. 2 Gain

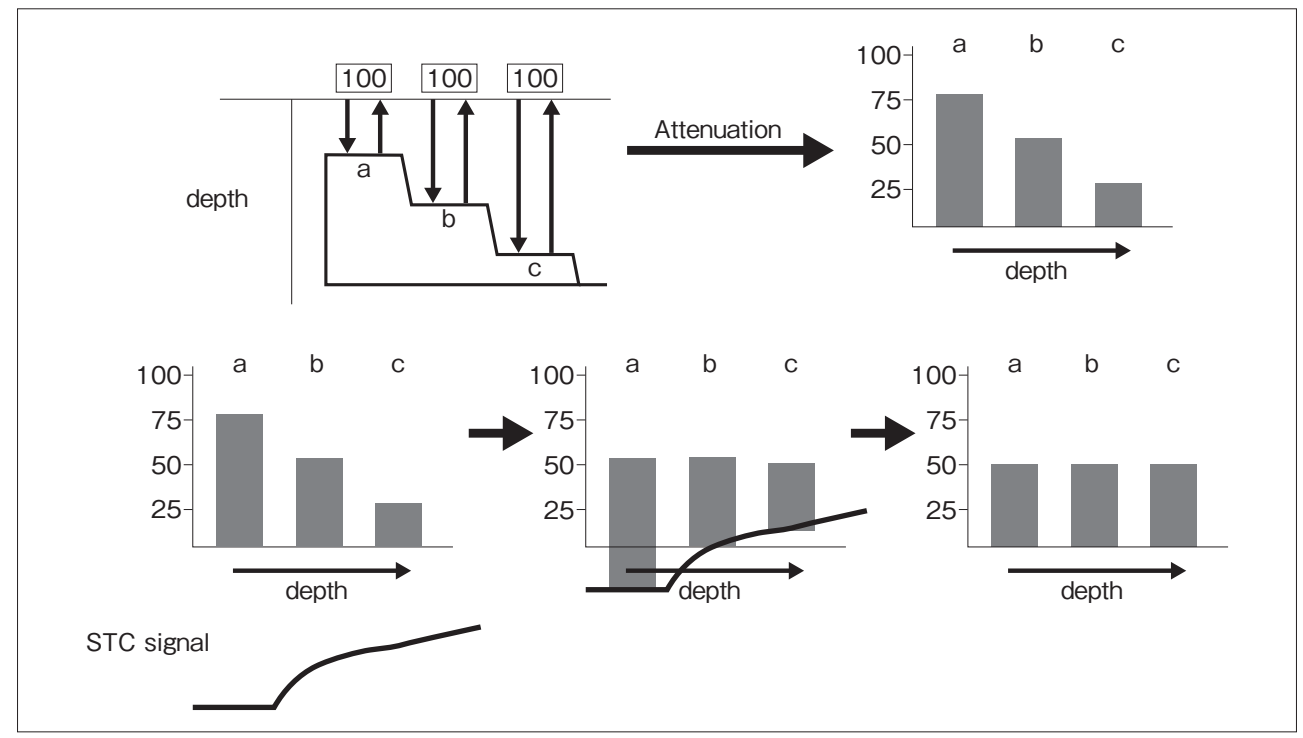

Fig. 3 Sensitivity time control (STC) or time gain compensation (TGC)

ンを変える機能である。体内から帰ってきた信号が弱 くてもこれを用いることにより，画像全体を均一な明 るさにすることができる (Fig. 3).

\section{5) 周波数}

周波数が高ければ, 解像度を高くすることができる が到達深度は浅くなる。また，ドプラ感度も低くなる，

6) フレームレート

1 秒間に何回画面を書き換えることができるかを表
す指標で, 単位は fps (frame per second)である.フレー ムレートが高いほど, 滑らかな画像となる.

7)流速レンジ

ドプラ法で表示できる流速の範囲を変えるつまみで ある.カラードプラ法で流速レンジを低く設定すると， レンジを超えた流速の血流は折り返し現象によりモザ イクパターンで表示され, 異常血流と正常血流との鑑 別が難しくなる。“何を見たいのか”を明確にしてレン ジを調節することが必要である。 


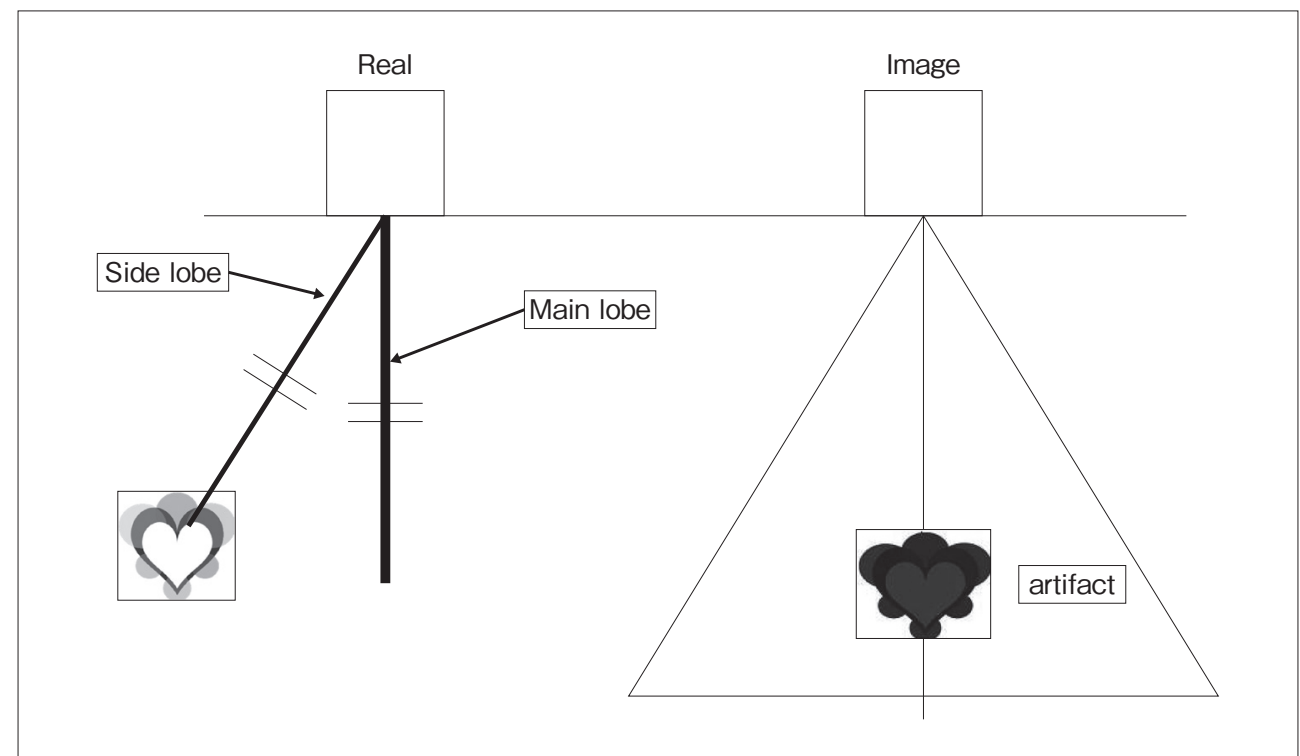

Fig. 4a Side lobe artifact

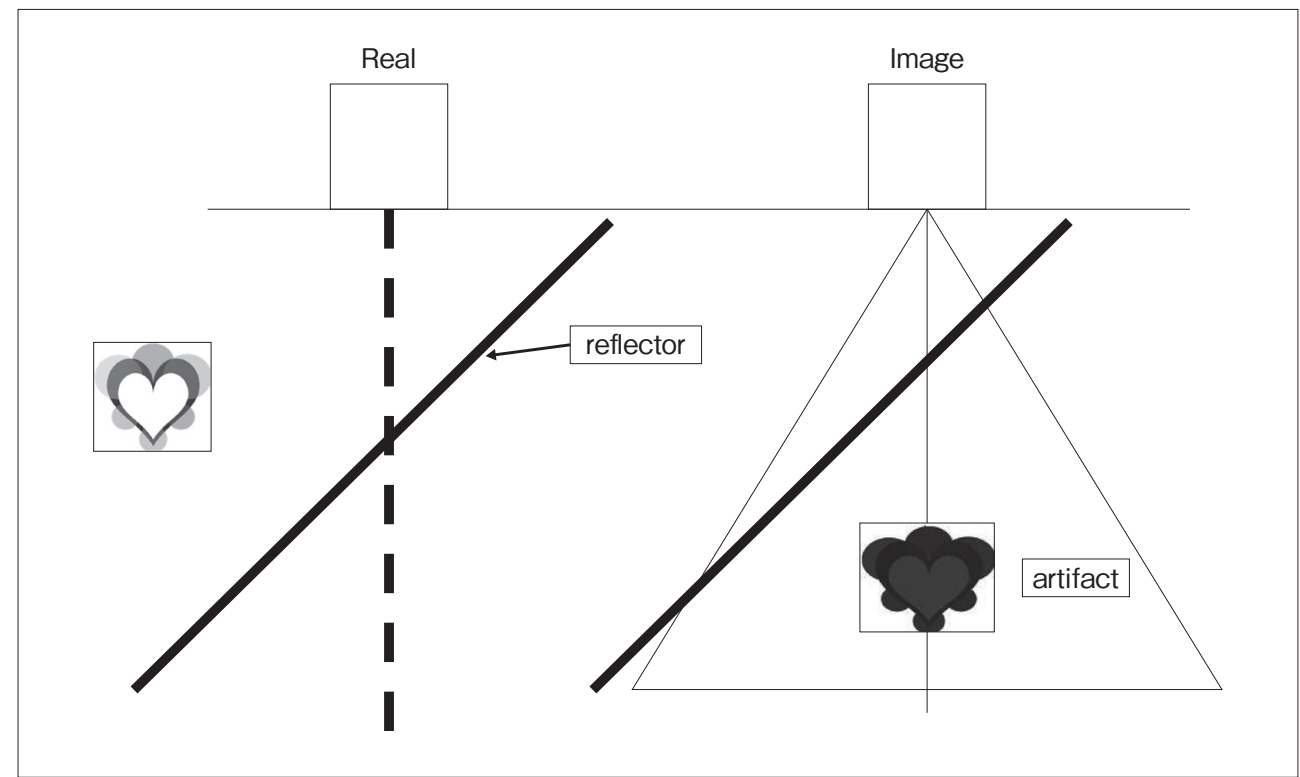

Fig. 4b Mirror image artifact

\section{2. アーチファクト}

超音波装置はいくつかの仮定のもとに画像を作って いる.すなわち

i。探触子から送信された超音波は直進して, 反射 も直進してくる.

ii. 探触子に入ってくる反射波はメインローブから の反射として認識する.

iii. エコー強度は反射の散乱強度に応じて表示さ れる。

iv. 音速は1,530 m/secで一定である，
などである。これらの仮定と異なる反射信号を探触子 が受診すると, 実際には存在しない場所に虚像が出現 したり, 逆に実際には存在する構造物が表示されない こともあり,これらがアーチファクトと呼ばれるもの である5).

\section{1. サイドローブ}

探触子から出されたビームはメインローブ以外にそ の外側にサイドローブを伴う。サイドローブのビーム が対象物に向かっていると，サイドローブによる反射 はあたかもメインローブによる反射のように，メイン 


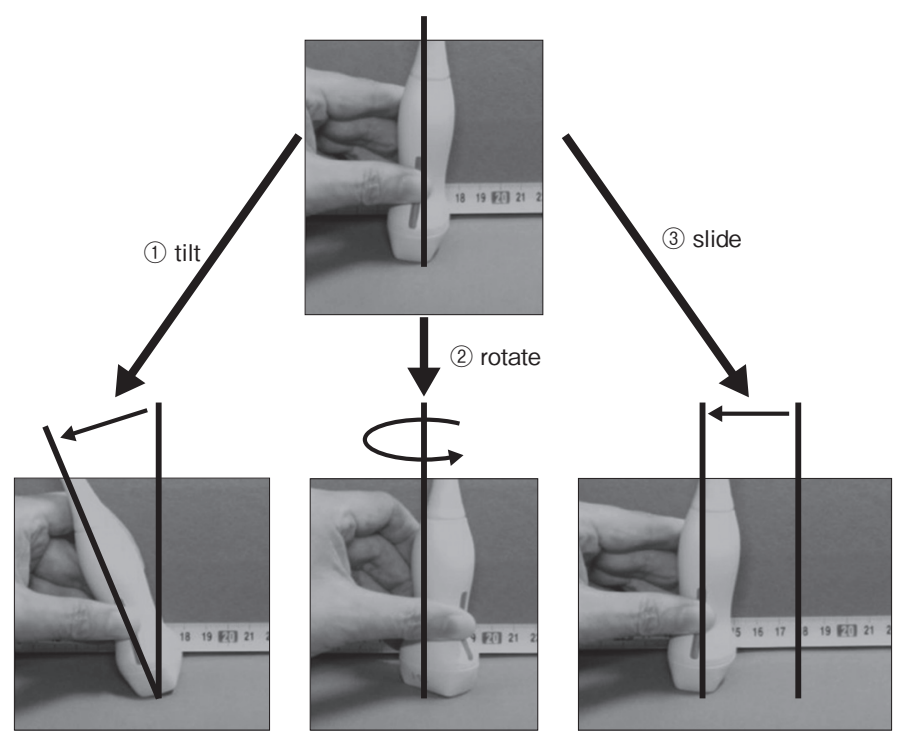

Fig. 5 Operation of the probe

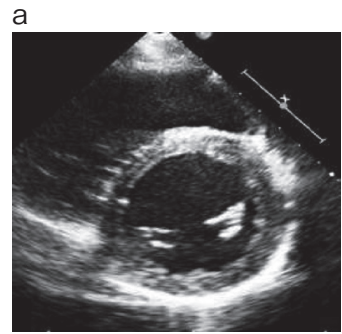

d

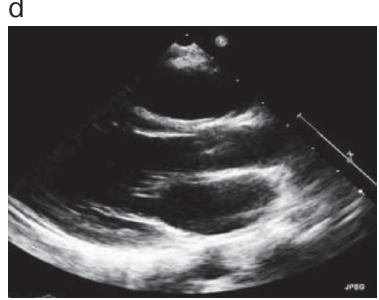

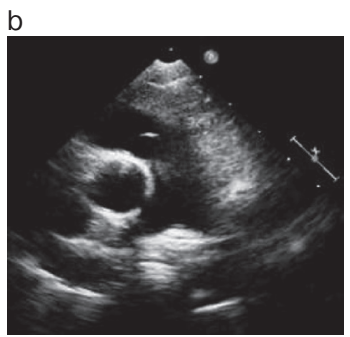

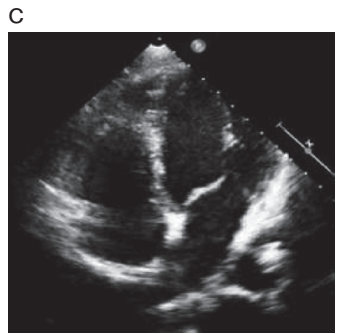

e

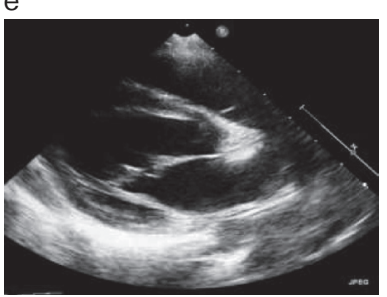

Fig. 6 Basic views

a: parasternal short axis view, ventricular level

b: parasternal short axis view, great vessels level

c: apical four chamber view

d: parasternal left ventricular long axis view

e: parasternal right ventricular outflow tract view

ローブが向かう位置に対象物があるように表示される (Fig. 4a).

\section{2. 多重反射，鏡面反射}

超音波は反射体と探触子の間で複数回反射を繰り返
すことにより, 実際の対象物の位置の整数倍の距離を 持つ位置に画像が出現する。

また，胸膜や横隔膜など面状の反射体が存在すると， 探触子の向かう方向と異なった位置に対象物があって も，あたかも探触子の向かう方向に対象物が存在する ように表示され，これを鏡面反射という(Fig. 4b). 
a

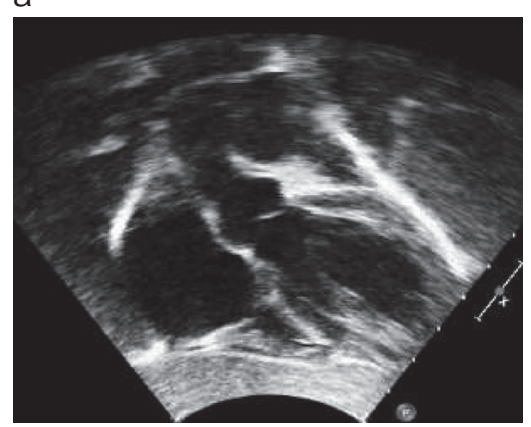

C

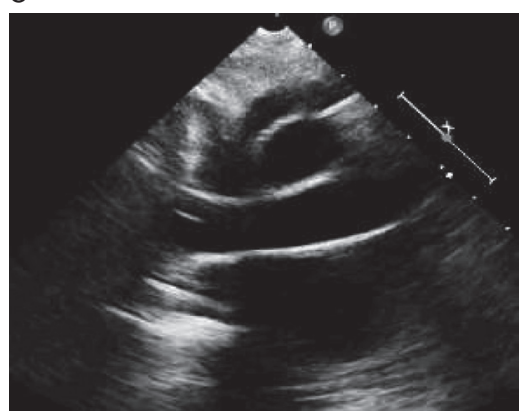

b

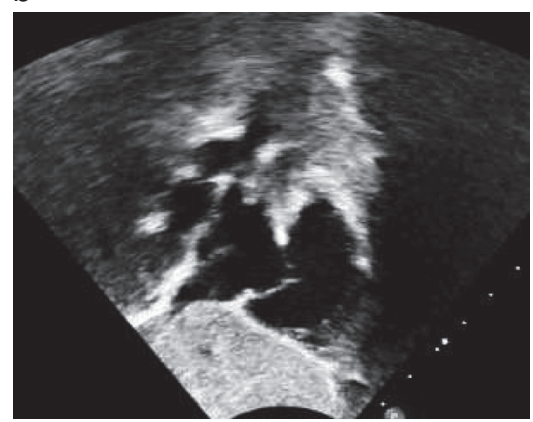

Fig. 7 Additional views

a: upside -down view, frontal plane from subxiphoid

b: upside -down view, sagittal plane from subxiphoid

c: frontal view from supra sternal notch

\section{3. 音響陰影}

強い反射体があると，ほとんどの超音波が反射され てしまい, その後方へは超音波が届かなくなり画像が 表示されなくなる。

\section{4. ドロップアウト}

対象物の厚みが薄く超音波ビームに対して平行に位 置すると反射が弱く, 描出されなくなることがある. 超音波ビームの方向と対象物が平行にならないように 探触子の位置を変えることにより解決する.

\section{3. 音響空と探触子操作の実際}

\section{1. 音響密}

超音波が目的の構造物まで到達しなければ, 画像は 作られない. 密度の高い構造物 (たとえば骨) は周囲の 軟部組織との間に音響インピーダンスの差が大きくな
るため探触子から出された超音波の大部分は反射され てしまい, その後方へ到達する超音波は非常に少なく なる(音響陰影)。そのため後方の構造物の画像は形成 されなくなるため画像が形成されにくくなる。した がって良好な音響空を得ることが重要である。

代表的な音響空は胸骨上窩, 胸骨左縁, 右縁の肋間, 心尖部，肋骨弓下などである。

\section{2. 探触子の持ち方と動かし方}

探触子のマーカーが親指の当たるほうにあるのかそ の逆なのかを意識する。画面にはマーカーのある側に 印がついているので, マーカーが体のどちらを向いて いるのかを確認する習慣を持たなければ, 左右や上下 を誤ることになる，検査時は，探触子をも持たない指 を被験者の体に当てて固定する. 探触子の動きは次の 3 種の動きが組み合わさったものである. 基本の動か し方は(1)傾ける, (2)まわす, (3)スライドさせる, である (Fig. 5).これらの3つの動きの違いを意識して動かす ことが重要である6,7).

(1) “傾ける (tilt)”とは, 探触子が皮膚に接している部分 
Table 2 Anatomical features of cardiac structures

\begin{tabular}{l|l|l|l}
\hline 心房 & & 右心房 & 左心房 \\
\hline & 心耳形態 & キャッチャーミット型(広い基部) & 人差し指型 \\
\hline & 静脈弁 & $\begin{array}{l}\text { 下大静脈弁(Eustachian valve) } \\
\text { 冠静脈洞弁(Thebesian valve) }\end{array}$ & なし \\
\hline & & & \\
\hline 心室 & & 右室 & 左室 \\
\hline & 形態 & おむすび型, 三角形 & 砲弾型, 狐の尻尾型, 椎の実型 \\
\hline & 肉柱 & 粗大 & 微細 \\
\hline & 乳頭筋 & $\begin{array}{l}\text { 主要乳頭筋 : 1 個 } \\
\text { 小乳頭筋 : 数個 }\end{array}$ & 主要乳頭筋 : 2 個 \\
\hline & 乳頭筋起始 & 中隔起始 & 自由壁からの起始 \\
\hline & 漏斗部 & あり & なし \\
\hline & & & 大動脈 \\
\hline 大血管 & & 肺動脈 & 弓を形成 \\
\hline & 形態 & すぐに分枝 & 頸部動脈を分枝 \\
\hline & & & あり \\
\hline & 冠動脈 & なし &
\end{tabular}

文献10,11より改変

はそのままにして，体に対して垂直に当てることを基 本の位置とし, 探触子を寝かせてその先端 (超音波ビー ム)加頭方向に向かうように寝かせることを, “頭方向 へ傾ける”と呼ぶ.

(2)“回す (回転) (rotate)”とは, 傾けるのと同様に, 探触 子を垂直に体に当てて, 接触部位や探触子の方向は変 えずに，上から見て時計方向，もしくは反時計方向に 回転させることを言う。

(3)“スライド (slide)”とは探触子をはじめに当てた状態 から，体に対する角度や方向を一定にして接触面をず らせることを言う。

通常はこれら 3 つ動きを無意識に同時に行ってい る.しかし，3つの動きをそれぞれ独立させて動かすこ とにより先天性心疾患の立体構造の理解を容易するこ とができる.

\section{4. 基本断面}

心エコー検查の有用性の一つに任意の断面が得られ ることがあげられる。しかし，一定のルールのもとに 画像を得なければ, 後に画像を見たときにどのような 断面なのかがわからなくなる，検査時に検者は理解し ていても，後で他人が見ると理解できないような画像 をしばしば見る。したがって誰が見ても理解できるよ うな “説得力のある画像”を撮るように心がけること が重要である。基本断面としては(1)心室短軸断面像, (2)大血管短軸断面, (3)四腔断面, (4)心室長軸断面であ り (Fig. 6a〜 e), これらの断面が正しく撮れていれば多
くの心疾患の診断は可能である.たとえどんなに緊急 時であってもこれらの基本断面を確実に記録すること が重要である，さらに小児では，(5)心窩部からの断面 (upside-down view), (6)胸骨上窩からの断面，は情報が 多く音響空が許せば記録しておくことが望ましい(Fig. $7 \mathrm{a} \sim \mathrm{c})^{6}$.

\section{5. 先天性心疾患の診断方法の基礎}

成人の虚血性心疾患や, 并膜症などでは, 基本構築 には異常がないことが前提となっている.しかし, 先 天性心疾患の中にはこの基本構築に異常があることが ある、したがって, 複雑に見える先天性心疾患を正し く、見落としのないように形態診断を行うには区分診 断法(segmental approach)が有用である ${ }^{8,9)}$. 区分診断法 は心臓の基本構築を診断する方法であり,これだけで 診断が完結するわけではないが先天性心疾患の診断の スタートとなるものである。

区分診断法は心臓の構成要素を心房, 心室, 大血管 の3つの区分に分けてそれぞれの位置を診断し，続い て心房一心室，心室－大血管の関係をそれぞれ順に決 定してゆく方法である。それには各構造物の形態学的 (解剖学的)特徵を心エコーで把握し, 各構成要素を正 しく認識することから始まる。

1. 心臟構成要素の解剖学的特徵と心エコーによる 同定方法

心臟の各部分にはそれぞれ解剖学的に特徵を持って 
いる(Table 2) ${ }^{10,11)}$ ，その特徵を心エコーで確認し同定 する，各構成要素の同定方法の詳細はここでは省略す るので成書を参照していただきたい99.

\section{2. 心エコーによる区分診断の進め方}

\section{1) Step 1, 心房位}

心窩部からの横断面と矢状断面を用いて決定する。

i，横断面：横隔膜面下で体の水平断面を見るよう に探触子をあてると，中央に椎体が逆U字型に見える。 このとき，椎体の右肩と左肩にそれぞれ血管が輪切り に見える、呼吸性変動がなく心拍動を認めるのが下行 大動脈であり，呼吸性変動を示すのが下大静脈である。 椎体の側壁に沿うように大動脈より深い位置で静脈が 見えるときは，右側であれば奇静脈，左側であれば半 奇静脈を考える。

ii. 矢状断面：単軸断面で同定した静脈を見ながら 探触子を 90 度回転させると, 椎体の右側で下大静脈が 心房に流入している様子を見ることができる。この下 大静脈が還流する心房を右房とする。したがって心房 位は正位 (situs solitus) となり，\{S. $\bigcirc . \bigcirc\}$ と記す。

また，大きな心房が一つしかない場合や下大静脈が 存在しない場合には不定位 (situs ambiguous) とし， $\{$ A. $\bigcirc . \bigcirc\}$ と記す. 奇 (半奇) 静脈結合があれば短軸断 面で見た大静脈が長軸にしても心房に流入せず，心臓 の背面を上行する様子が見られる。

\section{2) Step 2, 心室位}

心室の短軸断面で診断する。室位の診断は心臓を 正面から見て, 左室が右室の左側に位置すれば D-ルー プとなり, \{○.D. ○\} と記す．

単心室では後方にある痕跡的左室，もしくは前方に ある痕跡的右室(流出路腔)が確認できれば，心室の左 右関係は評価できる。しかし, 痕跡的心室が全く描出 できない場合には心室の左右関係の診断は不可能と なる。

心室が左右関係でなく，上下に配列することもある. この場合には心室の左右関係を論じることが困難であ ることが多いが，大血管のループがわかれば，大血管 のループを用いて, 心室ループを類推することもある (ループルール $)^{2,3)}$

\section{3) Step 3, 大血管位}

大血管の短軸断面を用いて診断する。このときそれ ぞれの半月弁のレベルで診断する. 2 つの大血管の関 係には左右関係と前後関係の 2 つの関係を組み合わせ
て診断する.すなわち, 正常心では左右関係を見ると 大動脈弁が肺動脈弁より右方にあり D の関係となる。 ついで前後関係を見ると, 大動脈弁が肺動脈弁より後 方に位置し，さらに大動脈と肺動脈はクロスするよう に走行する。したがって $\{\bigcirc . \bigcirc . D($ spiral $)\}$ と記すべき であるが,この場合は正常(normal)であるため単に $\{\bigcirc . \bigcirc . \mathrm{N}\}$ と記す。

大血管の左右関係は D で正常であっても, 前後関係 が逆転し大動脈が前方に, 肺動脈が後方に位置し, さ らに両大血管は平行に走行する場合には, 大血管関係 は前後関係が逆転しているため，大血管転位 (transposition)となり $\{$ ○.○.DT\} と記す（ただし，“T”を 略して単に“D”と記すことも多い).

両大血管の前後関係が同定できず，完全に左右同列 に並ぶ平行に走行することがある。また，左右関係が 同定できず全く前後関係になることもある。このよう な場合には心室のループを参照し大血管の左右関係を 類推する(ループルール).

\section{4) Step 4, 心房一心室関係}

Step1 から 3 までの診断を行い $\{\bigcirc . \bigcirc .0\}$ と書けば おおよその心臟の構造を示すことができるが，心房心 室関係には正常心のように三尖弁が右室へ, 僧帽弁が 左室へ挿入しているだけでなくいくつかの異常があ る。したがって， $\{○ . \bigcirc ． ○\}$ と記載した後に心房心室 関係の異常について追記する。

心房 - 心室関係の異常としては, 房室弁交差 (crisscrossing)，一側房室弁両室挿入 (straddling), 両房室弁同 室挿入 (double inlet)，一側房室弁閉鎖 (atresia)の 5 つの 場合が存在する ${ }^{10,11)}$.

\section{5) Step 5, 心室一大血管関係}

四腔断面から探触子を頭側に傾けて心室と大血管の つながりを確認するとともに, 心室の長軸断面により 房室弁と半月弁の間の線維性結合の有無をみる。

一つの心室から一つの大血管とさらに他の大血管の $50 \%$ 以上が起始している場合には両大血管右(左)室起 始症と診断することが一般的である。また，右室から 起始する血管は基本的に円錐を伴うため, その半月弁 と房室弁の間には線維性結合を認めず,筋肉組織が工 コーで認められる，完全大血管転位では左室から肺動 脈が, 右室から大動脈が起始する。 


\section{6. 血行動態, 心機能診断}

\section{1. 血行動態評価}

心エコー検査では形態診断を行うとともに，血行動 態の診断も同時に行う.カラードプラ法で容易に血流 情報が得られるが，それだけでは総合的な診断を誤る ことがある、そのためには心房，心室抢よび肺循環に かかる負荷の状態を様々な形態から診断し(負荷所見, 間接所見), カラードプラ法による直接的な所見と矛盾 が生じていないかどうかを検証することが重要で ある。

負荷所見と形態変化の関係は, 心室の負荷としては, 圧負荷 $\rightarrow$ 肥厚, 心室中隔の扁平化(右室圧上昇), 容量 負荷 $\rightarrow$ 拡大(容積の増大, エコーでは面積の増大), が 原則である。また, 肺血流の増加は肺血管径の拡張, 肺 血流の減少は肺血管径の減少となることが多い。さら に, 心房の拡大は還流血液量の増大もしくは房室弁の 逆流や狭窄が考えられる12).

圧較差の評価には連続波ドプラ法から得られる最大 流速から簡易ベルヌーイ式を用いる。簡易ベルヌーイ 式は

圧較差 $(\mathrm{mmHg})=4 \times$ 最大流速 $(\mathrm{v})^{2}$ であらわされる。しかし、ベルヌーイ式はエネルギー 保存の法則から導かれるものであり, 加速度による圧 変化や圧力損失さらに加速前の流速などが省略されて いるため“簡易”となっている。したがって多段階的 に加速するときには加速前の流速が無視できなくなる し, 狭窄の形態が砂時計型では圧回復が生じないため 圧較差を過大評価する。したがって, 最大流速を求め るだけでなくその前後の形態や速度変化にも注意をは らう必要がある。

このようにさまざまな負荷所見を示す疾患の鑑別診 断と疾患の組み合わせを考え, 形態診断と矛盾なく一 致したときに最終的にエコー診断とする.

\section{2. 心機能評価}

心機能を評価することは単純ではなく，心室全体の 評価と局所の評価さらに心室内の同期性，あるいは収 縮期と拡張期など各時相における機能やその時間的ず れなど，得られた指標が何を表現しているのかを正し く認識する必要がある。また, 右室についても同様な 評価が必要となり,さらに左室と右室の同期性や心房 の機能が果たす役割や心房と心室との同期性などにつ いてもさまざまな評価がなされている。
最近心エコーによる新しい指標が多数出現してい る。しかし心エコーにより得られる指標が “心機能” の中の何を示しているのか，またどこに限界があるの かを十分に理解せずに，ただ機械が算出した数字だけ をみることは危険である13)

以下に最近用いられるようになった指標について概 説する。

\section{1) 僧帽弁輪部心筋移動速度}

弁輪部の心筋の速度を組織ドプラ法で求めると拡張 期には心房から左室への流入か始まるとともに, 并輪 は心尖から遠ざかるように移動する。このときの速度 が $\mathrm{Em}(\mathrm{cm} / \mathrm{sec})$ である. 同様に心房収縮により左室が動 く動きが $\mathrm{Am}(\mathrm{cm} / \mathrm{sec})$ である。 また，収縮期にはこれと は逆に左室が小さくなるため僧帽弁輪は心尖部方向に 吊り上げられるように動く，このときの速度が $\mathrm{Sm}(\mathrm{cm} /$ sec)となる。

左室が駆出する直前(等容収縮期)に収縮を始めると きの動きの波が $\mathrm{C}$ 波 $(\mathrm{cm} / \mathrm{sec})$ であり，その加速度を Isovolumic acceleration(IVA) と呼ぶ.

収縮期の指標としては Sm が用いられることが多く 20 歳以下の健常人の正常值として $13.0 \pm 3.4 \mathrm{~cm} / \mathrm{sec} の$ データがある14).

拡張期の指標としては Em が広く用いられている。 さらに, 左室流入血流波形の $\mathrm{E}$ 波(急速流入波)の流速 を $\mathrm{Em}$ で除した $\mathrm{E} / \mathrm{Em}$ は左室拡張末期圧や左房圧を推 測するのに用いられている。この值が 15 を超えると有 意に左房圧が高いことが示されている15)。しかし，収 縮性心膜炎では Em が正常值よりも高值となることか ら, E/Em は左房圧と逆相関を示すことは注意が必要で ある16)

\section{2) 左室流入血流伝播速度 (flow propagation velocity : FPV)}

左室流入血流伝播速度は左室拡張能の指標として左 室への流入血流の速度が左室の弛緩能を表しているこ とから拡張能の指標として注目されている指標であ る. 左室流入血流に $\mathrm{M}$ モードのカーソルを当てて, カ ラー $\mathrm{M}$ モードを記録する。この傾きは左室流入血流が 左室中央部付近にまで到達する時間を示している。し たがって左室驰緩能が良好であれば, 流入血液が左室 中央部まで到達する時間は早いため, FPVは早くなり, また弛緩能が低下していればその速度が遅くなる。

\section{3）ストレイン, ストレインレート}

局所の心筋に注目しその心筋がどの程度, 収縮した かをみるのが局所心筋ストレインといわれるものであ 
る、ストレインは変化率をみたものであるが, 同じ量 の変化であってもゆっくり変化する場合と早く変化す る場合では収縮性は異なる。したがって, ストレイン をその変化に要した時間で割ったものがストレイン レートとなる。

2D スペックルトラッキング法から求める方法では 角度依存性はない。したがって, 左室について言えば 左室の心尖部方向への動き (longitudinal), 左室短軸の 円周方向の動き (circumferential), 左室短軸断面の中心 方向への動き (radial) とそれぞれの方向についてストレ イン, ストレインレートが求められることになる。

ストレインやストレインレートの最大值をとるタイ ミングを心時相のある一時点(多くは QRS) からの時間 として示すのが, time to peak strain(あるいは time to peak strain rate)である。この值が遅れている部位が虚血 を示すことが示されている ${ }^{17)}$. また，心筋各部位につ いてこの值のばらつきが心室の非同期性の指標として 用いられている18,19).

\section{おわりに}

超音波診断装置の進歩は目覚ましいものがあり，さ まざまな情報を瞬時に得ることができるようになって きている，しかし，いずれも組織から反射してきた超 音波を電気信号に変換し，さまざまな情報を得ている ことには変わりはない，したがって，基本となる超音 波の性質を知らなければ得られた情報に振り回される ことも起こり得る。また，どんなに超音波に関する知 識が豊富であっても, 疾患(病態)を知らなければ診断 することはできない，臨床医はこの超音波特性と疾患 をともに知ったうえで検査を行わなければどんなに高 価な装置も宝の持ち腐れとなる。

本稿が，心エコー検査の一助となれば幸いである。

\section{【参考文献】}

1) 日本超音波医学会編：新超音波医学 第 1 巻 医用超音波 の基礎. 東京, 医学書院, 2000

2)長井 裕, 伊東紘一: 絵でみる超音波改定第 2版. 東京, 南江堂, 2004

3) 奥山大太郎, 吉田泰夫: 超音波を用いた診断装置. 体外 循環技術. 1980；6：8-16

4) Itoh K, Yasuda Y, Suzuki O, et al: Studies on frequencydependent attenuation in the normal liver and spleen and in liver diseases, using the spectral-shift zero-crossing method. J Clin Ultrasound 1988；16：553-562
5) 瀬尾育式, 八木登志員：超音波アーチファクト. 吉川純 一(編): 臨床心エコー図学 第3版東京, 文光堂, 2008. pp25

6)富松宏文: 経胸壁心エコーの撮り方. 小児科診療 2012; 75: 917-927

7)富松宏文：リアルタイム心エコー動画像による遠隔診 断のための診断方法と用語の基準化の試み. 厚生労働科 学研究費補助金 (医療安全·医療技術評価総合研究事業) 分担報告書. 厚生労働科学研究費補助金地域医療基盤開 発推進総合研究事業：新生児重症心疾患に対する予後 向上のためのリアルタイム心エコー動画像による遠隔 診断と新生児心疾患救急診療システム確立に関する臨 床研究：(H18-医療 - 一般- 029) 平成 20年度総括 - 分担 研究報告書. 2009, p99

8) 里見元義: 先天性心疾患のための心断層エコー図. 東女 医大誌 $1980 ； \mathbf{5 0} ： 1-22$

9)里見元義：心臟超音波診断アトラス一小览・胎児編一 増補版. 東京,ベクトル・コア. 1999. pp22-27

10) 安藤正彦: 心臟の発生と形態. 高尾篤良, 門間和夫, 中澤 誠, 中西敏雄 (編): 臨床発達心臟病学 第3版. 東京, 中外 医学社, 2001, pp21-42

11) 安藤正彦: 心血管系の発生と先天性心奇形. 村田和彦, 細田瑳一(編): 循環器病学.東京, 医学書院, 1979. pp141160

12) 富松宏文: 先天性心疾患の診断の進め方. 循環器情報処 理 1999; 14: 69-75

13) 富松宏文: 心エコーによる心機能測定一最近の進歩一. 小児科 $2009 ； \mathbf{5 0} ： 449-459$

14) Eidem BW, McMahon CJ, Cohen RR, et al: Impact of cardiac growth on Doppler tissue imaging velocities: a study in healthy children. J Am Soc Echocardiogr 2004; 17: 212221

15) Hillis GS, Møller JE, Pellikka PA, et al: Noninvasive estimation of left ventricular filling pressure by $\mathrm{E} / \mathrm{e}^{\prime}$ is a powerful predictor of survival after acute myocardial infarction. J Am Coll Cardiol 2004; 43 : 360-367

16) Ha JW, Ommen SR, Tajik AJ, et al: Differentiation of constrictive pericarditis from restrictive cardiomyopathy using mitral annular velocity by tissue Doppler echocardiography. Am J Cardiol 2004; 94: 316-319

17) Pislaru C, Belohlavek M, Bae RY, et al：Regional asynchrony during acute myocardial ischemia Quantified by ultrasound strain rate imaging. L Am Coll Cardiol 2001; 37: 1141-1148

18) Suffoletto MS, Dohi M, Cannesson M, et al: Novel speckletracking radial strain from routine black-and-white echocardiographic images to quantify dyssynchrony and predict response to cardiac resynchronization therapy. Circulation 2006; 113: 960-968

19) Yu CM, Zhang QBM, Fung JWH, et al: A novel tool to assess systolic asynchrony and identify responders of cardiac resynchronization therapy by tissue synchronization imaging. J Am Coll Cardiol 2005: 45: 677-684 